\title{
Development and Validation of RP-HPLC Method for the Determination of Ganciclovir in Bulk Drug and in Formulations
}

\author{
P. J. Ramesh, K. Basavaiah, K. B. Vinay, and Cijo M. Xavier \\ Department of Chemistry, University of Mysore, Manasagangotri, Mysore 570006, India \\ Correspondence should be addressed to K. Basavaiah, basavaiahk@yahoo.co.in
}

Received 1 April 2012; Accepted 9 May 2012

Academic Editors: E. Boselli, F. M. Lancas, M. P. Marszall, and S. Sarker

Copyright () 2012 P. J. Ramesh et al. This is an open access article distributed under the Creative Commons Attribution License, which permits unrestricted use, distribution, and reproduction in any medium, provided the original work is properly cited.

A simple, rapid, accurate, and precise gradient reversed-phase HPLC (RP-HPLC) method has been developed for the determination of ganciclovir (GNC) in pharmaceuticals. Chromatographic separation was carried out on inertsil ODS $\mathrm{C}_{18}$ (4.6 $\mathrm{mm}$ i.d $\times 250 \mathrm{~mm}, 5.0 \mu \mathrm{m})$ LC column using ammonium acetate buffer, sodium salt of hexane sulfonic acid as ion-pairing reagent in $1000 \mathrm{~mL}$ water, and acetonitrile $(90: 10)(\mathrm{v} / \mathrm{v})$ as mobile phase at a flow rate of $1.0 \mathrm{~mL} \mathrm{~min}^{-1}$ and with UV detection at $245 \mathrm{~nm}$ at column temperature $\left(30^{\circ} \mathrm{C}\right)$. The runtime under these chromatographic conditions was $10 \mathrm{~min}$. The method was linear over the range of $0.02-75 \mu \mathrm{g} \mathrm{mL}{ }^{-1}$. The limits of detection (LOD) and quantification (LOQ) values were 4.1 and $20 \mathrm{ng} \mathrm{mL} \mathrm{m}^{-1}$, respectively. The method was successfully extended to study the effect on GNC upon treatment with $2 \mathrm{~N} \mathrm{NaOH}, 2 \mathrm{~N} \mathrm{HCl}$, and $5 \% \mathrm{H}_{2} \mathrm{O}_{2}$ for $2 \mathrm{hrs}$ at $80^{\circ} \mathrm{C}$ and upon exposure to UV $\left(1200 \mathrm{~K}\right.$ lux hrs) for $72 \mathrm{hrs}$ and thermal $\left(105^{\circ} \mathrm{C}\right)$ for 5 hrs. The proposed method was further applied to the determination of GNC in pharmaceuticals, with good percent recovery. The accuracy and the precision of the method were validated on intraday and interday basis in accordance with ICH guidelines.

\section{Introduction}

Ganciclovir (GNC), chemically known as 2-amino-9$\{[(1,3$-dihydroxypropan-2-1)oxy $]$ methyl $\}$-6,9-dihydro-3Hpurin-6-one (Figure 1), is a nucleoside analogue widely used in the treatment of cytomegalovirus infections.

It has proved to be effective against cytomegalovirus in immunocompromised patients, mainly in those with the acquired immunodeficiency syndrome (AIDS), congenital immunodeficiency, or in individuals following organ transplantation $[1,2]$. Various techniques have been developed for the determination of GNC in pharmaceuticals. It is official in the United States Pharmacopoeia [3], which describes an HPLC method for its determination in injections and in oral suspension.

The literature is enriched with several methods for the determination of GNC in pharmaceutical dosage forms including body fluids. The most extensively used technique for the quantitation of ganciclovir is HPLC, but most of the procedures using this technique are devoted to body fluids like plasma [4-14], plasma and tissues [15], serum
[16], and blood samples [17]. There is only one report [18] dealing with the application of HPLC for the determination of pharmaceutical formulations, that is eye drops. GNC in bulk drug and in its formulations has been assayed by UV spectrometry by measuring the absorbance of $0.1 \mathrm{M} \mathrm{HCL}$ and $0.1 \mathrm{M} \mathrm{NaOH}$ at 253 and $266 \mathrm{~nm}$, respectively [19]. The methods reported are moderately sensitive with molar absorptivity values of $2.0 \times 10^{3}$. Other reported methods for pharmaceuticals include visible spectrophotometry [2022], flow injection luminescence spectrometry [23], and radioimmunology [24-26]. The aim of this study was to develop an analytical HPLC method for sensitive, specific, and rapid determination of GNC in its tablets.

\section{Materials and Methods}

2.1. Materials and Standards. HPLC-grade acetonitrile (Labscan Asia Co. Ltd, Bangkok, Thailand), analytical reagent grade ammonium acetate (Rankem, Bangalore, India), and sodium salt of hexane sulfonic acid (Rankem, Bangalore, 


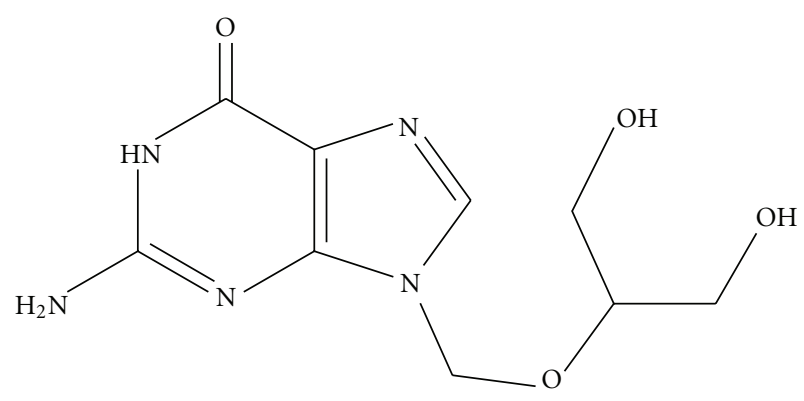

2-amino-9-\{[(1,3-dihydroxypropan-2-yl)oxy $]$ methyl $\}$-6,9-dihydro-3H-purin-6-one

FIGURE 1: Structure of ganciclovir.

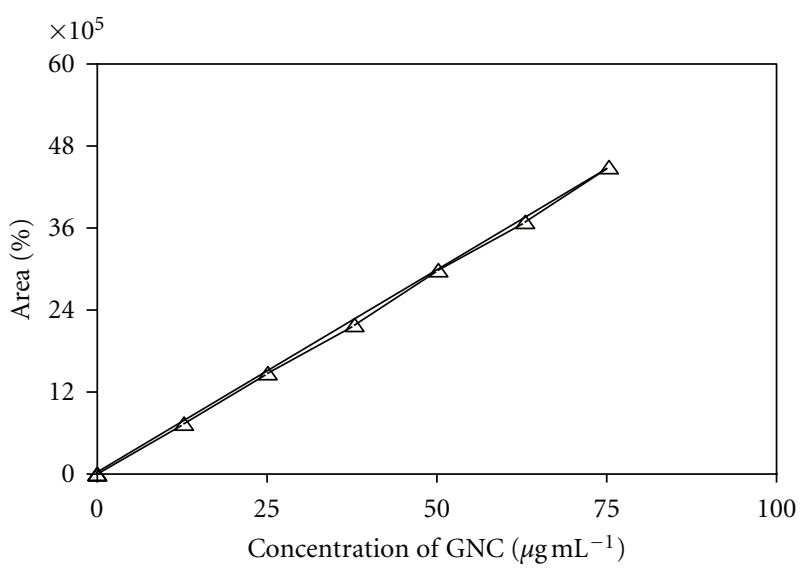

FIgURE 2: Linearity graph.

India) were used. Deionised, Milli Q water (Millipore, Bangalore, India) was used to prepare the mobile phase. Ganciclovir was obtained from Lotus Pharmaceuticals Ltd., Bangalore, India. Tablets were purchased from local commercial sources. A stock-standard solution equivalent to $1000 \mu \mathrm{g} \mathrm{mL}^{-1}$ GNC was prepared by dissolving accurately weighed amount of pure drug in the mobile phase.

2.2. Equipment. HPLC analysis was performed on an Alliance Waters HPLC system equipped with Alliances 2657 series low-pressure quaternary pump, a programmable variable wavelength UV-visible detector, Waters 2996 photodiode array detector, and auto sampler. Data were collected and processed using Waters Empower 2.0 software.

2.3. Chromatographic Conditions. Chromatographic analysis was carried out on an inertsil ODS-3V $\mathrm{C}_{18}(4.6 \mathrm{~mm}$ i.d $\times$ $250 \mathrm{~mm}, 5.0 \mu \mathrm{m})$ LC column. The mobile phase consisted of $0.025 \mathrm{M}$ ammonium acetate $(\mathrm{pH} \simeq 6.8)$ containing $0.4 \mathrm{~g}$ sodium hexane sulphonate and acetonitrile $(90: 10 \mathrm{v} / \mathrm{v})$. The mobile phase, filtered through $0.45 \mu \mathrm{m}$ membrane filter and degassed before use, was pumped at $1 \mathrm{~mL} \mathrm{~min}^{-1}$ flow rate. The column was thermostated at $30^{\circ} \mathrm{C}$. Under these conditions the runtime was $10 \mathrm{~min}$.

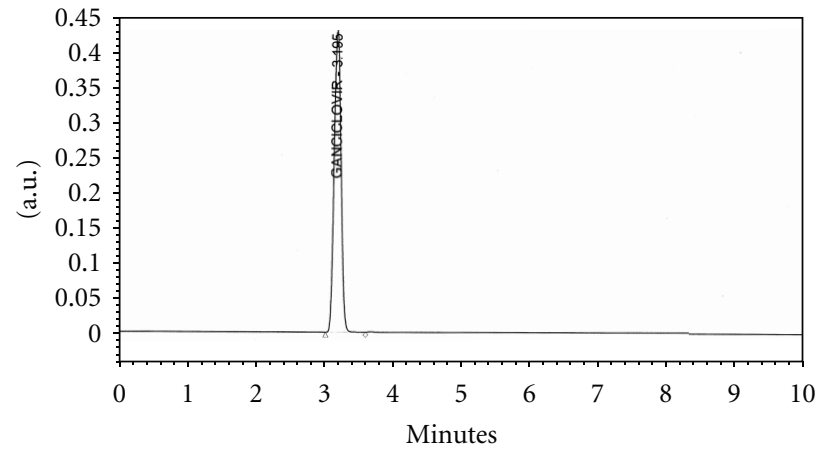

FIgUre 3: Typical chromatogram (pure GNC, $50 \mu \mathrm{g} \mathrm{mL}^{-1}$ ).

TABLE 1: Regression and sensitivity parameters.

\begin{tabular}{lc}
\hline Parameters & Value \\
\hline Linearity range, $\mu \mathrm{g} \mathrm{mL}^{-1}$ & $0.02-75$ \\
Slope $(b)$ & 59682.7532 \\
Intercept $(a)$ & -295296.2843 \\
Standard deviation of intercept $\left(S_{a}\right)$ & 235822.5161 \\
Standard deviation of Slope $\left(S_{b}\right)$ & 11483.1236 \\
Correlation coefficient $(r)$ & 0.9999 \\
Limit of detection $\left(\mathrm{LOD}, \mathrm{ng} \mathrm{mL} \mathrm{mL}^{-1}\right)$ & 4.1 \\
Limit of quantification $\left(\mathrm{LOQ}, \mathrm{ng} \mathrm{mL}^{-1}\right)$ & 20 \\
\hline${ }^{* *} Y=a+b X$, where $Y$ is the area and $X$ is the concentration in $\mu \mathrm{g} \mathrm{mL}^{-1}$.
\end{tabular}

\section{Procedures}

3.1. Calibration Graph. Ten $\mu \mathrm{L}$ of working standard solutions $\left(0.02-75 \mu \mathrm{g} \mathrm{mL}^{-1}\right.$ GNC) was injected automatically onto the column in triplicate and the chromatograms were recorded. The calibration graph was prepared by plotting the mean peak area percentage versus concentration in $\mu \mathrm{g} \mathrm{mL} L^{-1}$ (Figure 2).

3.2. Pharmaceutical Preparations. Twenty tablets were accurately weighed and crushed into a fine powder and mixed using a mortar and pestle. A quantity of tablet powder equivalent to $100 \mathrm{mg}$ of GNC was weighed accurately into a $100 \mathrm{~mL}$ calibrated flask, $50 \mathrm{~mL}$ of mobile phase as diluent added and was sonicated for $20 \mathrm{~min}$ to complete dissolution of the GNC, and the solution was then diluted to the mark with the diluent and mixed well. A small portion of the tablet solution (say $10 \mathrm{~mL}$ ) was withdrawn and filtered through a $0.2 \mu \mathrm{m}$ filter to ensure the absence of particulate matter. The filtrate was appropriately diluted with the diluent before injection into the column.

3.3. Results and Discussion. Mobile phases consisting of several buffering systems such as phosphoric acid, sodium acetate, potassium dihydrogen orthophosphate, sodium dihydrogen ortho phosphate or ammonium acetate with acetonitrile, methanol, and isopropanol as organic modifiers in different volumetric ratios failed to meet the required system parameters. Finally, the mobile phase consisting of $2.0 \mathrm{~g}$ ammonium acetate and $0.40 \mathrm{~g}$ of sodium salt of hexane 


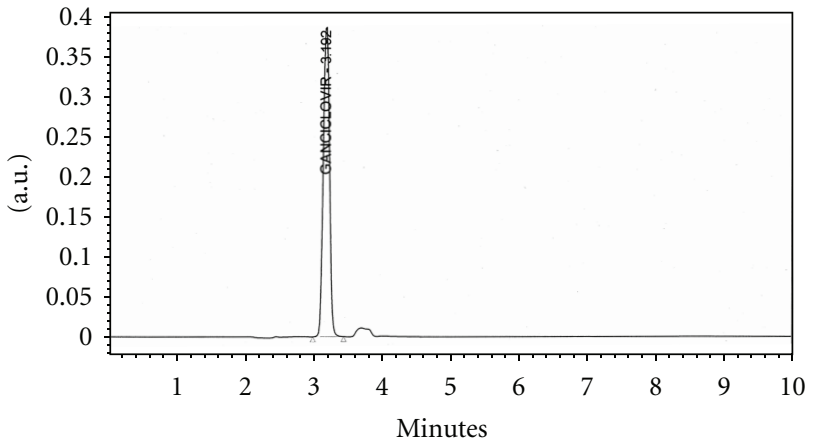

Figure 4: Chromatogram after forced degradation with $2 \mathrm{~N} \mathrm{HCl}$ at $80^{\circ} \mathrm{C}$ for 2 hrs (pure GNC, $50 \mu \mathrm{g} \mathrm{mL}^{-1}$ ).

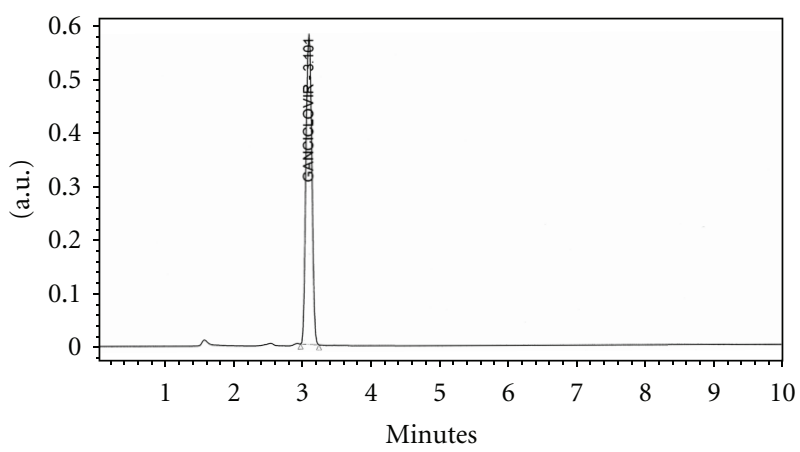

FIGURE 5: Chromatogram after forced degradation with $2 \mathrm{~N} \mathrm{NaOH}$ at $80^{\circ} \mathrm{C}$ for $2 \mathrm{hrs}$ (pure GNC, $50 \mu \mathrm{g} \mathrm{mL}^{-1}$ ).

sulphonic acid in $1000 \mathrm{~mL}$ water and acetonitrile $(90: 10$, $\mathrm{v} / \mathrm{v})$ was found to give better theoretical plates $(>2000)$ and tailing factor peak $(<1.2)$. The analysis was carried out at $30^{\circ} \mathrm{C}$, which besides being economical, offers many advantages like low-column back pressure, good chromatographic peak shape, improved column efficiency (1.14 tailing factor), higher theoretical plates (4732), and consistency in retention time. Under the stated chromatographic conditions, the mean retention time was $3.183 \mathrm{~min}(n=6)$. A model chromatogram is shown in Figure 3. Further, the optimized chromatographic conditions were used to study the effect on GNC after treatment with various stress conditions. Upon treatment with $2 \mathrm{~N} \mathrm{NaOH}, 2 \mathrm{~N} \mathrm{HCl}$, and $5 \% \mathrm{H}_{2} \mathrm{O}_{2}$, for 2 hrs at $80^{\circ} \mathrm{C}$, separately, there was no change in the retention time but there was a slight change in mean peak area in both $2 \mathrm{~N}$ $\mathrm{HCl}$ (Figure 4) and $2 \mathrm{~N} \mathrm{NaOH}$ (Figure 5), and there was a significant change in both peak areas but no change in retention time in $5 \% \mathrm{H}_{2} \mathrm{O}_{2}$ (Figure 6). There was no effect upon exposure to UV at $1200 \mathrm{~K}$ lux (Figure 7) and thermal treatment at $105^{\circ} \mathrm{C}$ (Figure 8), for $5 \mathrm{hrs}$.

\section{Method Validation}

4.1. Linearity. Working standard solution of GNC $\left(1000 \mu \mathrm{g} \mathrm{mL}^{-1}\right)$ was appropriately diluted with the diluent solution to obtain solutions in the concentration range $0.02-$ $75 \mu \mathrm{g} \mathrm{mL}^{-1}$ GNC. Ten $\mu \mathrm{L}$ of each solution was injected

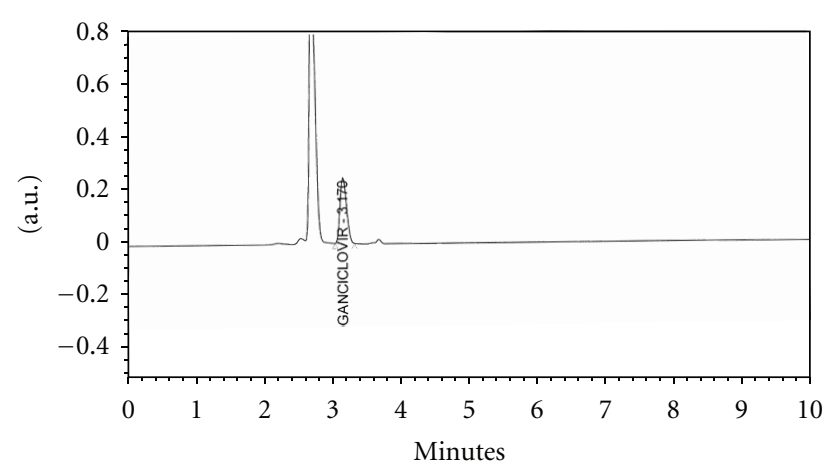

Figure 6: Chromatogram after forced degradation with 5\% $\mathrm{H}_{2} \mathrm{O}_{2}$ at $80^{\circ} \mathrm{C}$ for $2 \mathrm{hrs}$ (pure GNC, $50 \mu \mathrm{g} \mathrm{mL} L^{-1}$ ).

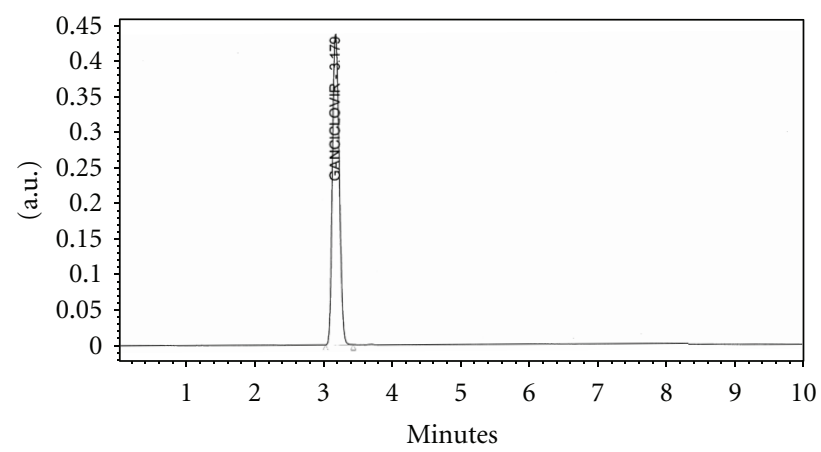

Figure 7: Chromatogram after exposure to UV at $1200 \mathrm{~K}$ lux hrs for $72 \mathrm{hrs}$ (pure GNC, $50 \mu \mathrm{g} \mathrm{mL} \mathrm{m}^{-1}$ ).

in triplicate onto the column under the operating chromatographic conditions described above. Calibration curve was constructed by plotting the mean peak area percentage versus concentration. The least squares method was used to calculate the slope $(b)$, intercept $(a)$, and the correlation coefficient $(r)$ of the regression line. The relation between mean peak area $Y(n=3)$ and concentration, $X$ expressed by the equation $Y=a+b X$, was linear. Values of slope, intercept, and correlation coefficient $(r)$ were $59682.7532,-295296.2843$, and 0.9999 , respectively. A plot of log peak area versus log concentration was a straight line with the slope of 0.9969 indicating excellent linearity between mean peak area and concentration in the range $0.02-75 \mu \mathrm{g} \mathrm{mL}^{-1} \mathrm{GNC}$ as shown in Table 1 .

4.2. Limits of Detection (LOD) and Quantification (LOQ). LOD and LOQ were estimated from the signal-to-noise ratio. The LOD defined as the lowest concentration that gave a peak area with signal-to-noise ratio between 2-3 was found to be $4.1 \mathrm{ng} \mathrm{mL}^{-1}$. The lowest concentration that provided a peak area with a signal-to-noise ratio 9.68, which is called LOQ, was found to be $20 \mathrm{ng} \mathrm{mL}^{-1}$.

4.3. Specificity. Method specificity was checked by comparing the chromatograms obtained for pure GNC solution, synthetic mixture, tablet solution, and placebo blank. An examination of the chromatograms of the above solutions 
TABLE 2: Intraday and interday accuracy and precision.

\begin{tabular}{|c|c|c|c|c|c|c|c|c|}
\hline \multirow{2}{*}{$\begin{array}{l}\mathrm{GNC} \\
\text { Injected, } \\
\mu \mathrm{g} \mathrm{mL}^{-1}\end{array}$} & \multicolumn{4}{|c|}{ Intraday accuracy and precision } & \multicolumn{4}{|c|}{ Interday accuracy and precision } \\
\hline & $\begin{array}{c}\text { GNC found } \\
\mu \mathrm{g} \mathrm{mL}^{-1}\end{array}$ & $\begin{array}{c}\mathrm{RE}, \\
\%\end{array}$ & $\begin{array}{c}\mathrm{RSD}^{\mathrm{b}}, \\
\%\end{array}$ & $\begin{array}{c}\mathrm{RSD}^{\mathrm{c}}, \\
\%\end{array}$ & $\begin{array}{c}\text { GNC found } \\
\mu \mathrm{g} \mathrm{mL}^{-1}\end{array}$ & $\begin{array}{c}\mathrm{RE}, \\
\%\end{array}$ & $\begin{array}{c}\mathrm{RSD}^{\mathrm{b}}, \\
\%\end{array}$ & $\begin{array}{c}\mathrm{RSD}^{\mathrm{c}}, \\
\%\end{array}$ \\
\hline 25.0 & 25.4 & 1.6 & 0.85 & 0.06 & 25.3 & 1.2 & 1.12 & 0.33 \\
\hline 50.0 & 50.9 & 1.8 & 0.20 & 0.25 & 51.0 & 2.0 & 0.86 & 0.42 \\
\hline 75.0 & 76.1 & 1.5 & 0.62 & 0.16 & 77.2 & 2.9 & 1.14 & 0.26 \\
\hline
\end{tabular}

${ }^{\mathrm{a}}$ Mean value of seven determinations, ${ }^{\mathrm{b}}$ based on peak area, ${ }^{\mathrm{c}}$ based on retention time.

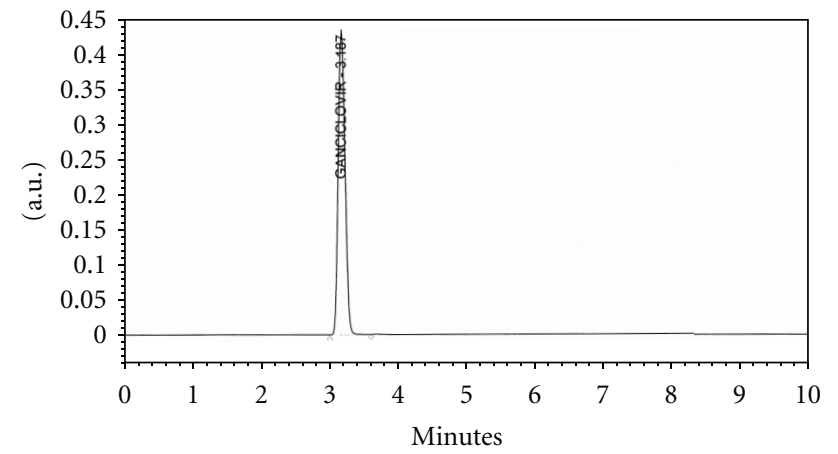

FIGURE 8: Chromatogram after thermal treatment at $105^{\circ} \mathrm{C}$ for $5 \mathrm{hrs}$ (Pure GNC, $50 \mu \mathrm{g} \mathrm{mL}^{-1}$ ).

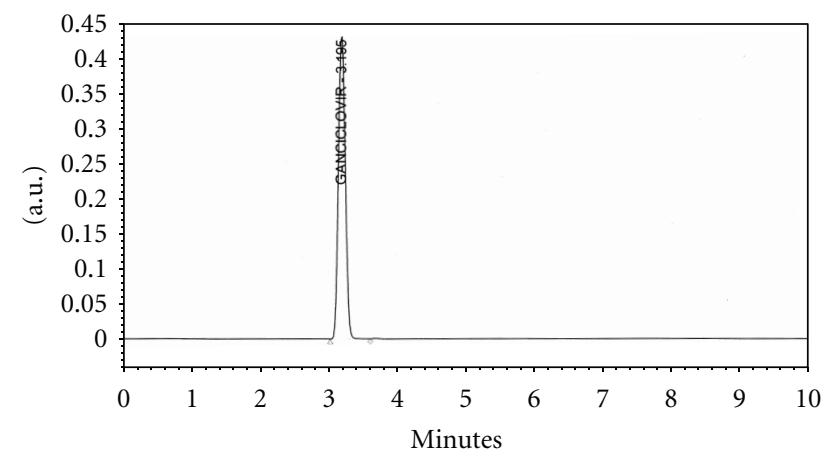

FIGURE 9: Chromatogram of synthetic mixture (GNC, $50 \mu \mathrm{g} \mathrm{mL}^{-1}$ ).

shown in Figures 3, 9, 10, and 11 reveals the absence of peaks due to additives present in tablet preparations.

4.4. Precision and Accuracy. Method precision was determined from the results of six independent determinations of GNC at three different concentrations, 25, 50, and $75 \mu \mathrm{g} \mathrm{mL}^{-1}$ on the same day. The interday and intraday relative standard deviation (RSD) values for peak area and retention time for the selected concentrations of GNC were less than 2.0 and $0.5 \%$, respectively. The method accuracy, expressed as relative error (\%), was determined by calculating the percent deviation found between concentrations of GNC injected and concentrations found from the peak area. This study was performed by taking the same three concentrations of GNC used for precision estimation. The intraday and interday accuracy (expressed as \%RE) values which are $<2.9 \%$ are also compiled in Table 2.

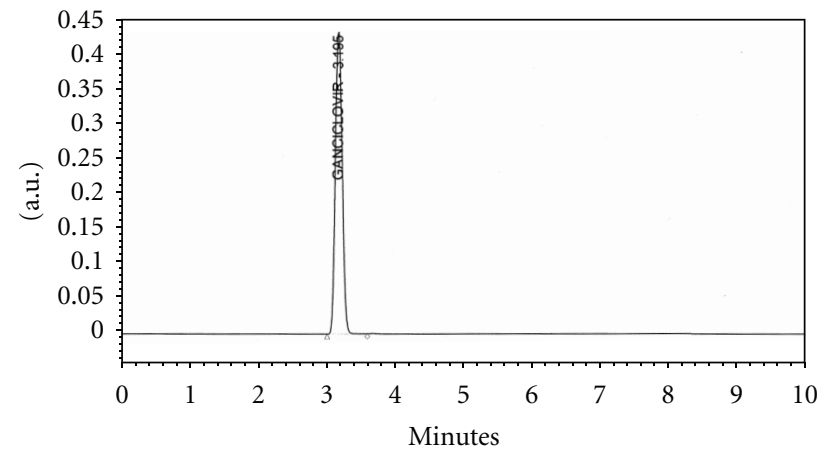

Figure 10: Chromatogram of tablet solution (GNC, $50 \mu \mathrm{g} \mathrm{mL}^{-1}$ ).

4.5. Robustness. To determine the robustness of the method, small deliberate changes in the chromatographic conditions like flow rate and column temperature were made, and the results were compared with the original chromatographic conditions. The results indicated that changing the flow rate $( \pm 0.1 \mathrm{~mL})$ had some effect on the chromatographic behavior of GNC. However, the alteration in the column temperature $\left( \pm 2^{\circ} \mathrm{C}\right)$ had no significant effect. The results of this study expressed as \%RSD are summarized in Table 3.

4.6. System Suitability. System suitability parameters were measured to verify the system performance and the values of retention time, number of theoretical plates and tailing factor were $3.17 \pm 0.1,4732$ per column and 1.14 , respectively. All the values were within the acceptable range.

4.7. Solution Stability. The stability of standard and sample solutions was determined by monitoring the peak area and retention time over a period of $24 \mathrm{hrs}$ by injecting the solutions at the intervals of $0,8,16$, and $24 \mathrm{hrs}$. The standard and sample solutions were stored at ambient temperature $\left(25^{\circ} \mathrm{C}\right)$ and protected from light during the stability study. No changes in drug concentrations were observed over a period of $24 \mathrm{hrs}$ as shown by the small \%RSD values. The $\%$ RSD for peak area $(n=3)$ was $1.93 \%$ for pure drug solution and the value for retention time $(n=3)$ was $1.43 \%$. The results are presented in Table 4 . No significant changes in concentration of the active ingredient were observed in the tablet solution as well.

4.8. Method Application. The developed and validated method was successfully applied to determine GNC in 


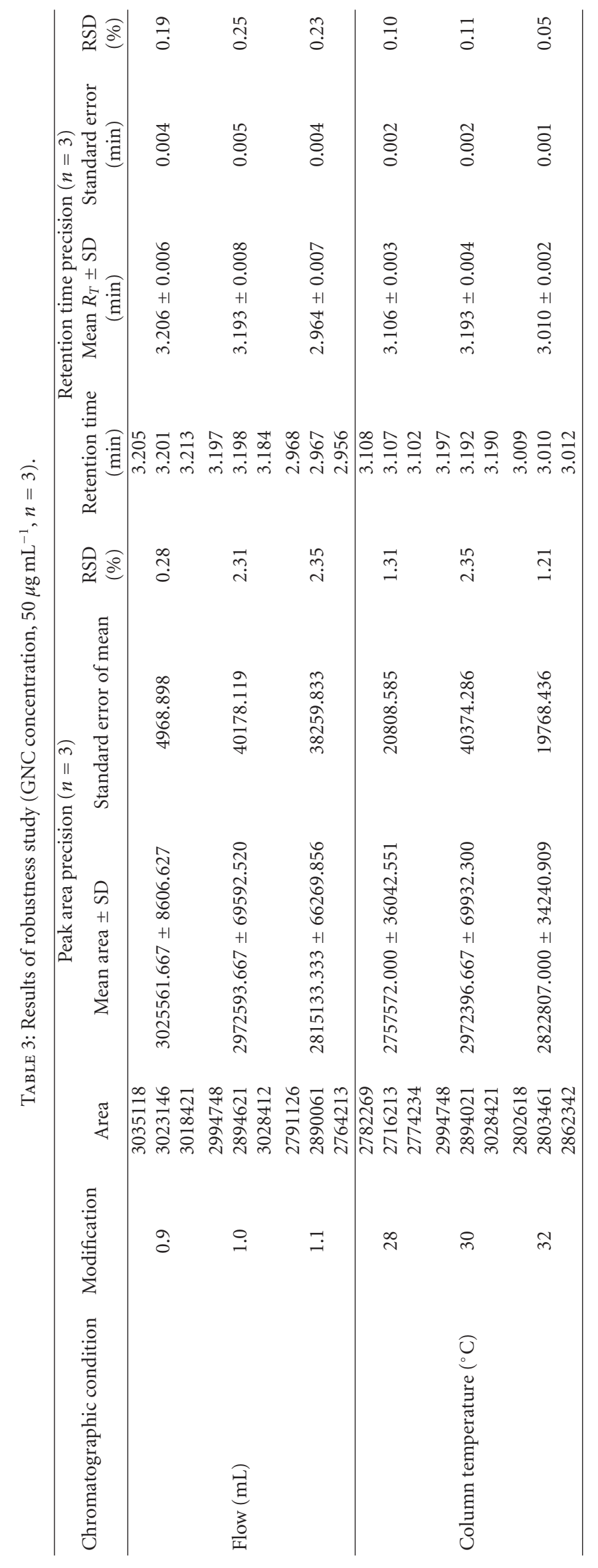


TABLE 4: Solution stability (GNC concentration was $50 \mu \mathrm{g} \mathrm{mL}^{-1}$ ).

\begin{tabular}{|c|c|c|c|c|c|c|}
\hline Time, hrs & Peak area & Mean \pm SD & $\%$ RSD & Retention time $(\min )$ & Mean \pm SD & $\%$ RSD \\
\hline & 2989840 & & & 3.195 & & \\
\hline \multirow[t]{3}{*}{0} & 2895622 & $2929008 \pm 52766$ & 1.80 & 3.185 & $3.164 \pm 0.05$ & 1.43 \\
\hline & 2901562 & & & 3.112 & & \\
\hline & 2845671 & & & 3.158 & & \\
\hline \multirow[t]{3}{*}{8} & 2859782 & $2831673 \pm 37143$ & 1.31 & 3.145 & $3.139 \pm 0.02$ & 0.07 \\
\hline & 2789565 & & & 3.115 & & \\
\hline & 2946830 & & & 3.118 & & \\
\hline \multirow[t]{3}{*}{16} & 2985633 & $2936679 \pm 54740$ & 1.86 & 3.156 & $3.141 \pm 0.02$ & 0.64 \\
\hline & 2877574 & & & 3.148 & & \\
\hline & 2908480 & & & 3.149 & & \\
\hline \multirow[t]{2}{*}{24} & 2858942 & $2855884 \pm 54189$ & 1.90 & 3.102 & $3.119 \pm 0.03$ & 0.83 \\
\hline & 2800231 & & & 3.106 & & \\
\hline
\end{tabular}

TABLE 5: Results of determination of GNC in tablets and statistical comparison with the reference method.

\begin{tabular}{|c|c|c|c|c|c|}
\hline \multirow{2}{*}{ Tablet brand name** } & \multirow{2}{*}{ Nominal amount, $\mathrm{mg}$} & \multicolumn{4}{|c|}{ Found* (percent of label claim \pm SD) } \\
\hline & & Reference method & Proposed method & Student's $t$-value (2.77) & $F$-value $(6.39)$ \\
\hline Ganguard $^{1}$ & 500 & $98.51 \pm 1.05$ & $99.62 \pm 1.85$ & 1.05 & 3.10 \\
\hline Natclovir $^{2}$ & 250 & $99.06 \pm 0.88$ & $100.1 \pm 1.61$ & 2.31 & 3.34 \\
\hline
\end{tabular}

${ }^{*}$ Mean value of five determinations, ${ }^{* *}$ marketed by: ${ }^{1}$ Ranbaxy Lab, Ahamedabad, India, ${ }^{2}$ Natco Pharma Ltd., Pune, India, figures in the parenthesis are the tabulated values for four degree of freedom at $95 \%$ confidence level.

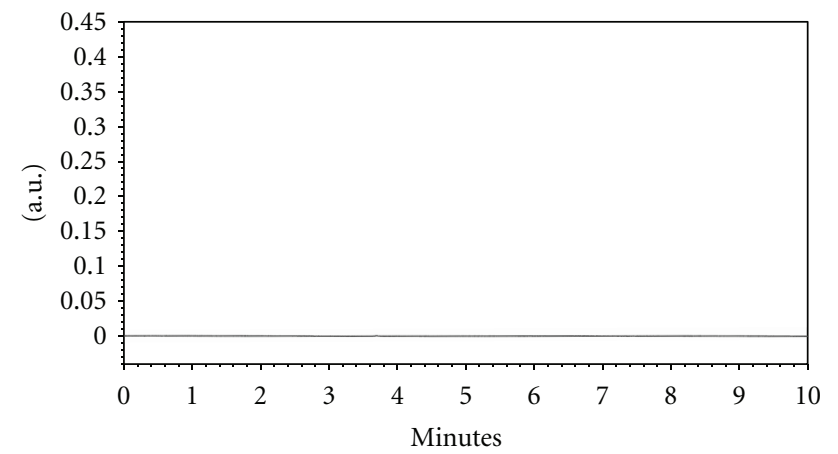

Figure 11: Chromatogram of placebo blank.

tablets. The results obtained tallied closely with the labeled amount in the case of tablets (Table 5), thus indicating the utility of the method for content uniformity evaluation. The results were statistically compared with those obtained by reported method [19] for accuracy and precision by applying the Student's $t$-test and variance ratio $F$-test. The reference method consisted of the measurement of the tablet extracts absorbance at $253 \mathrm{~nm}$. The calculated $t$ - and $F$-values were less than the tabulated values of 2.77 and 6.39 at the $95 \%$ confidence level and for five degrees of freedom suggesting that there was significant difference between the proposed method and the reference method with respect to accuracy and precision.

4.9. Recovery Study. To the preanalyzed tablet powder, pure GNC was added at three levels and the total was found by the proposed method. Each measurement was triplicated. When the test was performed on $500 \mathrm{mg}$ and $250 \mathrm{mg}$ tablets, the percent recovery of pure GNC was 106.15 and 102.10 with standard deviation of 0.86 and 0.46 , respectively. The results indicate that the method is very accurate and that common excipients found in tablet preparations do not interfere and the results are summarized in Table 6 .

\section{Conclusions}

Very simple, cost effective, accurate, and precise RP-HPLC method for determining ganciclovir was developed and validated as per the ICH guidelines Q2 (2005). Analysis was carried at ambient temperature. Besides, short retention time (3.117), runtime (10 $\mathrm{min})$, and flow rate $\left(1 \mathrm{~mL} \mathrm{~min}^{-1}\right)$ make the method attractive since these features help in saving cost and time of analysis. Ammonium acetate has many properties which are particularly interesting for use on a general purpose buffer [27] the most significant being low toxicity and cost, easy availability, good buffering capacity in the chosen $\mathrm{pH}$ range, and ability to provide greatly improved separations without column deterioration. In summary, this method is selective, sensitive, rapid, and reproducible for ganciclovir in its tablets. The precision and accuracy are within acceptable ranges, the quantification limit is as low as $20 \mathrm{ng} \mathrm{mL}^{-1}$ [27], and finally the assay is robust and rugged.

\section{Acknowledgments}

Authors thank Lotus Pharmaceuticals Ltd., Bangalore, India for providing the pure sample of ganciclovir as gift. Three of the authors (P. J. Ramesh, K. B. Vainay, and C. M. Xavier) thank the authorities of the University of Mysore, Mysore, for 
TABLE 6: Results of recovery study by standard addition method.

\begin{tabular}{lcccc}
\hline Tablet & GNC in tablet, $\mu \mathrm{g} \mathrm{mL}^{-1}$ & Pure GNC added, $\mu \mathrm{g} \mathrm{mL}^{-1}$ & Total found, $\mu \mathrm{g} \mathrm{mL}^{-1}$ & Pure GNC recovered ${ }^{*}$ percent \pm SD \\
\hline \multirow{3}{*}{ Ganguard 500 mg } & 26 & 12.5 & 39.12 & $101.90 \pm 0.16$ \\
& 26 & 25 & 52.05 & $100.55 \pm 0.72$ \\
\hline \multirow{3}{*}{ Natclovir 250 mg } & 26 & 37.5 & 64.18 & $106.15 \pm 0.86$ \\
& 24.9 & 12.5 & 38.03 & $101.30 \pm 0.64$ \\
& 24.9 & 25 & 51.88 & $102.10 \pm 0.46$ \\
\hline
\end{tabular}

* Mean value of three determinations.

permission and facilities. The same authors are indebted to the Jubilant Lifesciences Ltd., Nanjangud, Mysore, India, for their kind permission to pursue Ph.D. degree programme.

\section{References}

[1] H. L. Cantrill, K. Henry, N. H. Melroe, W. H. Knobloch, R. C. Ramsay, and H. H. Balfour, "Treatment of cytomegalovirus retinitis with intravitreal ganciclovir. Long-term results," Ophthalmology, vol. 96, no. 3, pp. 367-374, 1989.

[2] A. Markham and D. Faulde, "Ganciclovir: an update of its therapeutic use in cytomegalovirus infection," Drugs, vol. 48, pp. 455-460, 1994.

[3] "The United States Pharmacopoeia," XXIV Revision, the National Formulary XIX Rockville, USP Convention, P. 2482, 2000.

[4] D. R. Weller, H. H. Balfour, and H. E. Vezina, "Simultaneous determination of acyclovir, ganciclovir, and (R)-9-[4hydroxy-2-(hydroxymethyl)butyl] guanine in human plasma using high-performance liquid chromatography," Biomedical Chromatography, vol. 23, no. 8, pp. 822-827, 2009.

[5] A. Maes, B. Garré, N. Desmet et al., "Determination of acyclovir in horse plasma and body fluids by high-performance liquid chromatography combined with fluorescence detection and heated electrospray ionization tandem mass spectrometry," Biomedical Chromatography, vol. 23, no. 2, pp. 132-140, 2009.

[6] Y. J. Dao, Z. Jiao, and M. K. Zhong, "Simultaneous determination of aciclovir, ganciclovir, and penciclovir in human plasma by high-performance liquid chromatography with fluorescence detection," Journal of Chromatography B, vol. 867, no. 2, pp. 270-276, 2008.

[7] M. Kasiari, E. Gikas, S. Georgakakou, M. Kazanis, and I. Panderi, "Selective and rapid liquid chromatography/negativeion electrospray ionization mass spectrometry method for the quantification of valacyclovir and its metabolite in human plasma," Journal of Chromatography B, vol. 864, no. 1-2, pp. 78-86, 2008.

[8] N. Perrottet, A. Beguin, P. Meylan et al., "Determination of acyclovir and ganciclovir in human plasma by liquid chromatography-spectrofluorimetric detection and stability studies in blood samples," Analytical Technologies in the Biomedical and Life Sciences, vol. 852, no. 1-2, pp. 420-429, 2007.

[9] F. Schenkel, S. Rudaz, Y. Daali, M. K. Oestreicher, J. L. Veuthey, and P. Dayer, "Development and validation of a new reversed-phase ion pairing liquid chromatographic method with fluorescence detection for penciclovir analysis in plasma and aqueous humor," Journal of Chromatography B, vol. 826, no. 1-2, pp. 1-7, 2005.
[10] D. Teshima, K. Otsubo, T. Yoshida, Y. Itoh, and R. Oishi, "A simple and simultaneous determination of acyclovir and ganciclovir in human plasma by high-performance liquid chromatography," Biomedical Chromatography, vol. 17, no. 8, pp. 500-503, 2003.

[11] S. Kishino, Y. Takekuma, M. Sugawara et al., "Liquid chromatographic method for the determination of ganciclovir and/or acyclovir in human plasma using pulsed amperometric detection," Journal of Chromatography B, vol. 780, no. 2, pp. 289-294, 2002.

[12] N. Shibata, A. Kitamura, Y. Yoshikawa, T. Inoue, T. Bamba, and K. Takada, "Simultaneous determination of aciclovir and ganciclovir in plasma by HPLC and pharmacokinetic interactions," Pharmacy and Pharmacology Communications, vol. 6, no. 11, pp. 501-506, 2000.

[13] R. Boulieu, N. Bleyzac, and S. Ferry, "High-performance liquid-chromatographic determination of ganciclovir in plasma," Journal of Chromatography, vol. 105, no. 2, pp. 480484, 1991.

[14] T. Yoshida, R. Takahashi, K. Imai, H. Uchida, Y. Arai, and T. Oh-Ishi, "A simple, sensitive determination of ganciclovir in infant plasma by high-performance liquid chromatography with fluorescence detection," Journal of Chromatographic Science, vol. 48, no. 3, pp. 208-211, 2010.

[15] S. D. Brown, C. A. White, and M. G. Bartlett, "Hydrophilic interaction liquid chromatography/electrospray mass spectrometry determination of acyclovir in pregnant rat plasma and tissues," Rapid Communications in Mass Spectrometry, vol. 16, no. 19, pp. 1871-1876, 2002.

[16] M. Koel and P. Nebinger, "HPLC determination of serum ganciclovir using ultrafiltration, ultraviolet and fluorescence detection," Journal of Pharmaceutical and Biomedical Analysis, vol. 12, no. 3, pp. 429-432, 1994.

[17] R. Boulieu and N. Bleyzac, "Stability of ganciclovir in blood samples," Journal of Pharmaceutical and Biomedical Analysis, vol. 12, no. 9, pp. 1205-1207, 1994.

[18] G. L. Liangand and Henan, "HPLC determination of ganciclovir and ribavirin in eye drops," Yaowu Fenxi Zazhi, vol. 26, no. 9, pp. 1308-1310, 2006.

[19] S. P. Sarsambi, A. Sonawane, S. M. Malipatil, B. Hiremath, and A. Faheem, "Spectrophotometric estimation of ganciclovir in bulk drug and its formulation," International Journal of PharmTech Research, vol. 2, no. 2, pp. 1264-1268, 2010.

[20] P. Schelling, G. Folkers, and L. Scapozza, "A spectrophotometric assay for quantitative determination of kcat of herpes simplex virus type 1 thymidine kinase substrates," Analytical Biochemistry, vol. 295, no. 1, pp. 82-87, 2001.

[21] A. A. Gouda, "Utility of certain $\sigma$ - and $\pi$-acceptors for the spectrophotometric determination of ganciclovir in 
pharmaceutical formulations," Talanta, vol. 80, no. 1, pp. 151$157,2009$.

[22] S. Prakash, P. S. Sarsambi, D. Gowrisankar, A. Sonawane, and A. Faheem, "Visible spectrophotometric determination of ganciclovir by condensation and oxidative coupling reactions," International Journal of ChemTech Research, vol. 2, no. 1, pp. 282-285, 2010.

[23] N. N. Wang, Y. Tang, X. Xiong, X. Han, and C. Yu, "A new flow-injection chemiluminescence method for the determination of acyclovir and gancyclovir," Analytical Letters, vol. 39, no. 5, pp. 973-983, 2006.

[24] J. P. Sommadossi and R. Bevan, "High-performance liquid chromatographic method for the determination of 9(1,3-dihydroxy-2-propoxymethyl)guanine in human plasma," Journal of Chromatography, vol. 414, no. 2, pp. 429-433, 1987.

[25] C. Nerenberg, S. McClung, J. Martin, M. Fass, J. Lafarque, and S. Kushinsky, "A radioimmunoassay procedure for the determination of the antiviral nucleoside DHPG (9-[(1,3dihydroxy-2-propoxy)-methyl]guanine) in plasma or serum," Pharmaceutical Research, vol. 3, no. 2, pp. 112-115, 1986.

[26] S. M. Tadepalli, R. P. Quinn, and D. R. Averett, "A competitive enzyme-linked immunosorbent assay to quantitate acyclovir and BW B759U in human plasma and urine," Antimicrobial Agents and Chemotherapy, vol. 29, no. 1, pp. 93-98, 1986.

[27] F. Bailey, "Applications of high performance liquid chromatography in the pharmceuticl industry," Journal of Chromatography, vol. 122, pp. 73-84, 1976. 


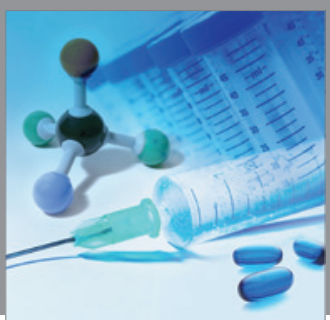

International Journal of

Medicinal Chemistry

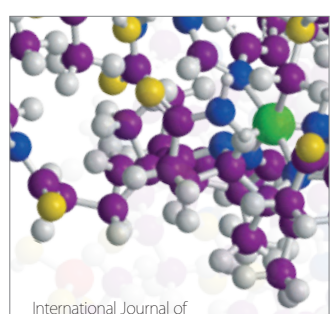

Carbohydrate Chemistry

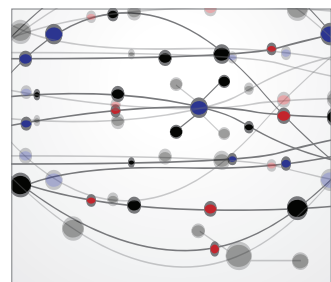

The Scientific World Journal
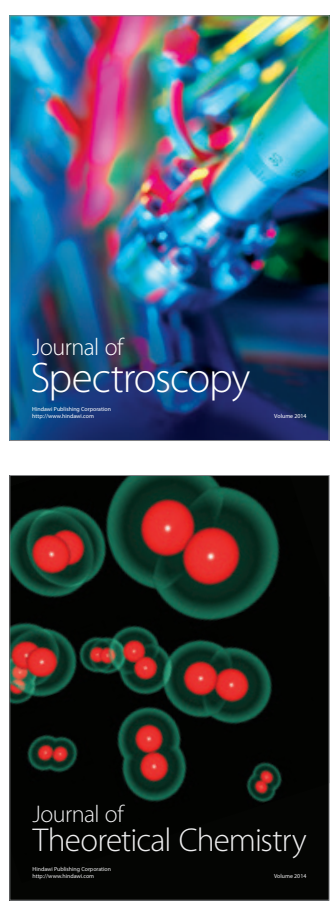
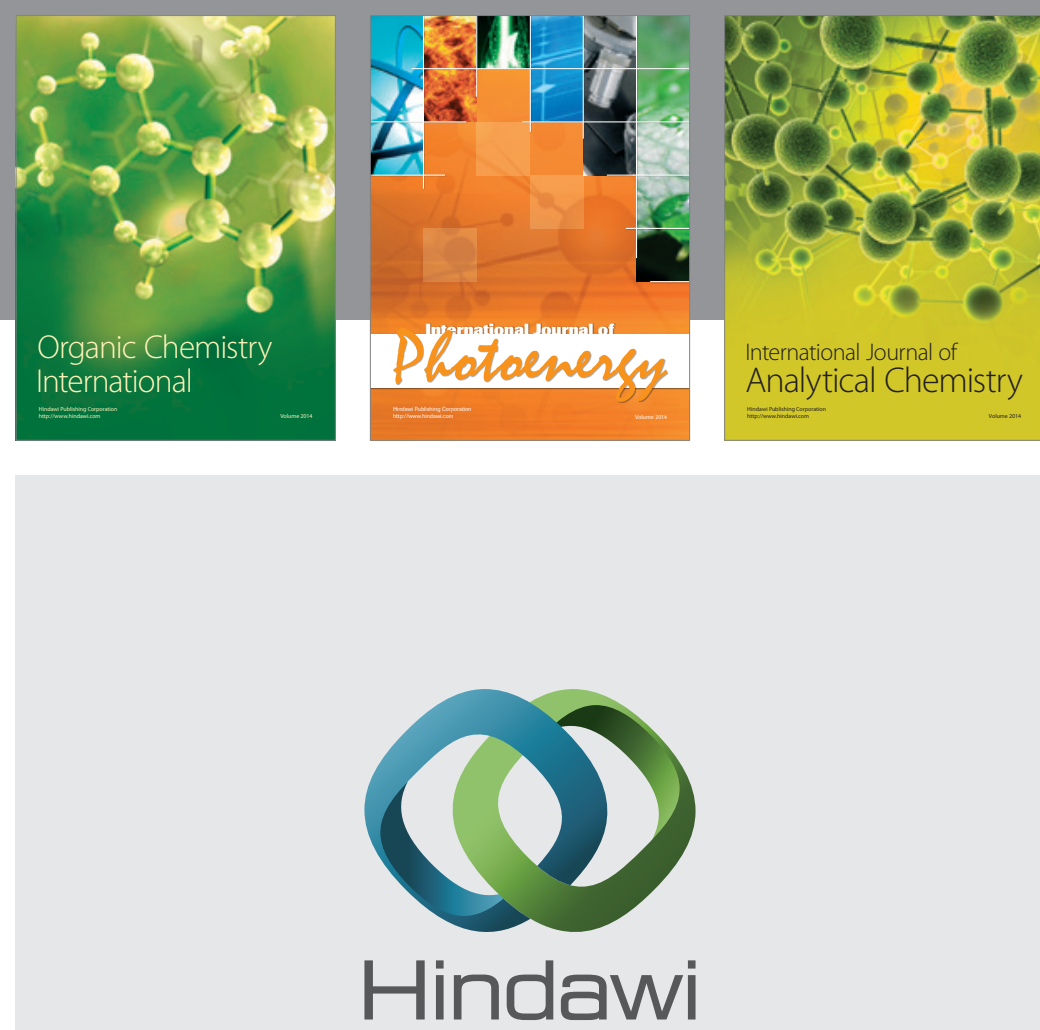

Submit your manuscripts at

http://www.hindawi.com
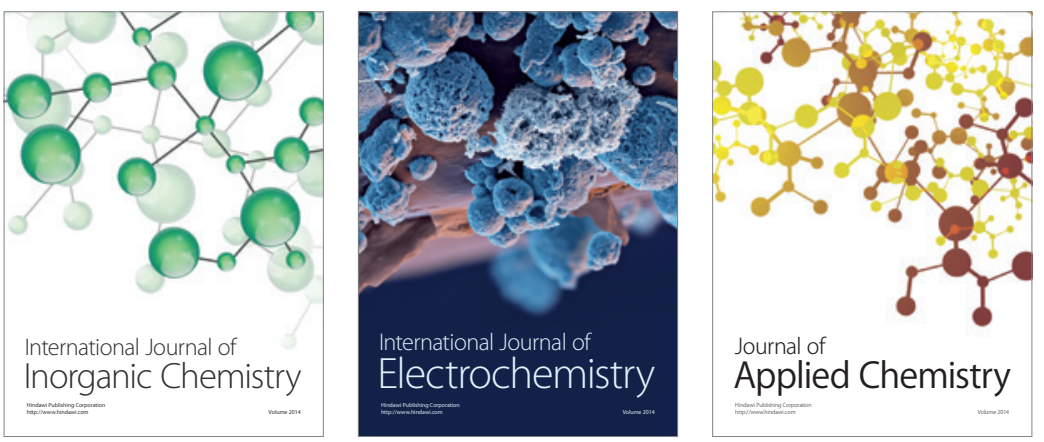

Journal of

Applied Chemistry
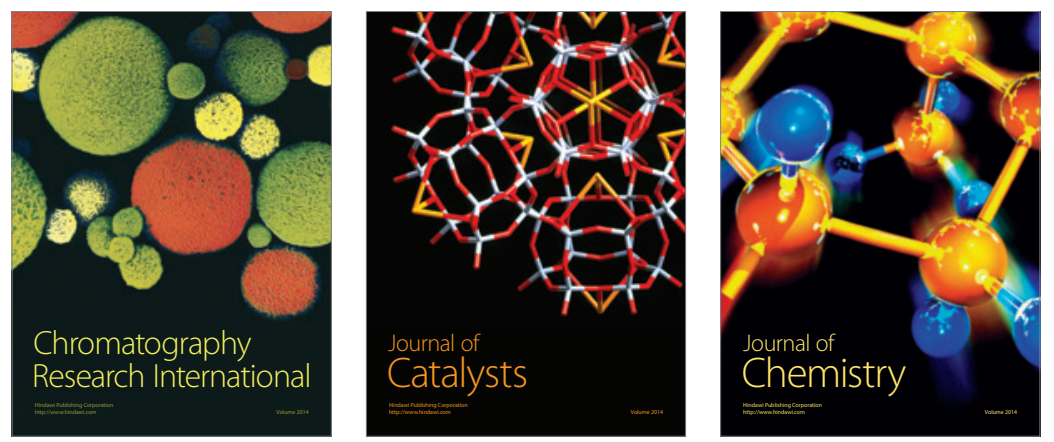
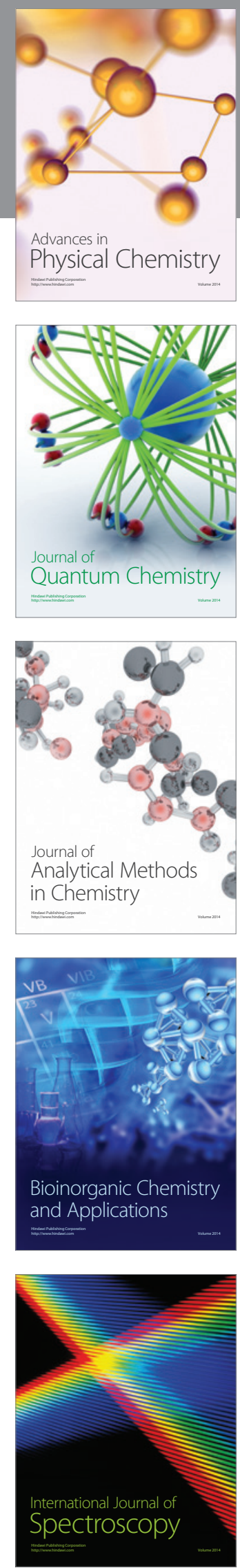